\title{
Quo Vadis Teaching Literary Criticism
}

\section{Suryo Tri Saksono, Imron Wakhid Harits, Štefan Chudý}

\begin{abstract}
Literature comes to its readers/audience with complexity and uniqueness. Behind literature, there are authors that bring morality, religion, and other hidden missions. Literary criticism works to reveal every element in literature. It bridges the authors' agenda and the audience's needs. Aware with these complicated tasks, literary criticism has to face the problematic challenges: define its focus of analysis or let itself goes everywhere to follow the authors' agenda and the audience's needs.
\end{abstract}

Keywords: literature, literary critic, literary criticism, focus of analysis.

\section{Introduction and general overview}

Literary criticism is description and evaluation of its object; the primary concern of criticism is about the problem of unity - a kind of whole which the literary work forms or fails to form, and the relation of various parts to each other in building up this whole. Soon after being published, a work of literature will fight criticisms. The author of the work has to be ready for various consequences; they can be positive, but no one can guarantee that they will be negative. Of course, literary criticism is not completely negative; 'critic' is etymologically related to 'criteria'; a literary critic is a judge, not a denouncer (Posner 2008: 388). A provoking statement appears in Aristophane's Frogs (1008-1010), authors were in charge with the task of making human better (Destrée 
and Murray 2015: 57). This duty is very heavy to be carried out. Literary works are different according to religion. Literary works talk about beautiful and not beautiful, while religion discusses the right and the wrong. Consequently, when philosophers bring literature and morality together, it is time to ask, roughly what is the impact of morally charged content on literary value (Hagberg and Jost 2015: 101). This phenomenon complicates the problem.

Moreover when we look at the turn of the $20^{\text {th }}$ and $21^{\text {st }}$ centuries in the environment of globalization and integration of social conditions, the humanitarian thought has undergone tremendous changes, which is particularly evident in the development of national literatures. The shift of spiritual-moral as well as social-esthetical values and cultural reference points became a huge trial for the oral lore (Gilazov et al. 2015: 72). This trend leads to a complexity in conducting criticism towards literature.

A shift in focus in criticism could also point to a shift in the way we consume literature. Television shows and films which come to our homes often make us consumptive. We, then, are reluctant to enjoy literature. When we come to this condition, we have to realize that this worldview has been provoked by corporate interests, and we have to realize that this is not a single truth. Almost every phenomenon has clear origins and possible alternatives when no longer treated as a given fact of life (Huber 2015: 95)

\section{Literary criticism: the phenomena}

Literary analyses try to reveal the complexity. They examine individual texts or genres to describe what authors do, looking, for example, at narrative patterns, character development, symbolism, intertextuality, or the function of the setting (Stephens 2015: 105). Through this 'duty', literary critics are expected to convey the true 'spirit' of the author (Schultz 2015: 61).

The subject-matter of literary criticism is an art, and criticism is evidently some kind of art too. This sounds as though criticism is a parasitic form of literary expression, art based on pre-existing art, a second-hand imitation of creative power (Frye 2015: 87). Even though it is supposed to be second-hand, however, if we look at the nature, it belongs to literature, because of literariness which makes of a given work a work of literature or work of art. By literariness is meant implementation of literary devices in a given piece of literature (M. A. H. Khan 2015: 69).

A literary work has belonged to an organized whole considered as a historical occurrence and thus been brought into one of the 'orders' that societies strive to build. Insofar as it did so belong, the individual work of art did not merely become an additional unit in a sum of separate units. It entered a structural whole, a system, among whose parts significant and reciprocal relations existed. The inability to perceive these relations is what Guillen calls the 'atomistic fallacy' in literary studies (Guillen 2015: 201). 
It is also unwise to neglect the relation between literature and its readers. Take a look at the relationship of the so-called 'advice' literature to its readers. Regaignon emphasizes that advice literature makes a particularly attractive puzzle because of the way it thematizes readerly compliance, the way its rhetorical confidence seems to elide the gap between representation and action (Regaignon 2015: 25).

Works of literature exist in the world to respond to social, psychological, and political forces operant at the time of their writing, that they take part in forming the systems of beliefs upon which people act, individually and collectively, and that those belief systems continue to have an effect long after the time of their initial construction (Cheney and Silberman 2015: 83). Take a look at Pound. Several decades after his death, his influence over the proverbial landscape of American poetry is undeniable, and proponents of the poetic avant-garde in the late 1970s to 1990s posited that Pound's influence over American poetic form is dominant because of its subversive, political nature (Foltz 2015: 77).

Some authors also try to enrich their works by mirroring other authors. One of them is Ralph Waldo Ellison. Other writers who influence him include Fyodor Dostoyevsky, Herman Menville, Mark Twin, T. S. Eliot, Henry James, William Faulkner, and Andre Malraux (Nelson 2015: 110). A different way is taken by Andrew Marvell. His lyric poems go around a very narrow area. It is a mosaic floor, delicately worked in intricate patterns of great variety, with a great deal of forethought; within the narrow limits that he chose, Andrew Marvell wrote fantastic variations upon his few themes (Colie 2015: 39). This is the reason why artists in general, and the poets principally, have been confined in so narrow circle; they have been rather imitators of one another than of nature (Howells 2015: 123).

A similar phenomenon also happens to Nussbaum. Some of her best works were beautifully created after her readings of Henry James, probably her most persuasive case for a turn to ethics in literary studies. They have helped to encourage a literary ethics that considers literariness and ethico-moral insight as two sides of the same coin, implying, for instance, that somehow Henry James's superior narrative skills contribute to the moral depth of his vision, which makes him all the more literary (Leypoldt 2008: 146).

Many people admire literature because of its genius to bring reality into the world of imagination as they also admire a painting because its beauty portrays real things. Bender argues that people admire poems for representing, as if they were real, things which are unreal but probable inventions. Painting is a literal art, but poetry is an imaginative one (Bender 2015: 68). Mikhail Bakhtin, however, once reminded us that language in literature lies on the borderline between oneself and the other. The word in language is half someone else's. It becomes "one's own" only when the speaker populates it with his own intention, his own accent, when he appropriates the word, adapting it to his own semantic and expressive intention (Gates Jr and Mitchell 2014: 94). Wherever it comes to the readers, then the readers occupy the other half. 
Hans Robert Jauss writes that a literary work is not a 'monument' that monologically reveals its timeless essence. A literary event can continue to have an effect only if those who come after it still or once again respond to it - if there are readers who again appropriate the past work or authors who want to imitate, outdo, or refute it (Marsden 2015: 143). Further Jauss figured out. A literary work exists only when it has been re-created or concretised in the mind of its reader. Later on, this idea will inspire the theory of structuralism and post structuralism. We often find this valuable literary work in classical literature. Unfortunately, however, Mark Twain once defined a 'classic' as 'a book which people praise but don't read' (Harris 2015: 55).

When literature talks about a narrative moment recurs in a certain pattern within a given geographical space and becomes, through the force of repetition, the means or only way for (mis) understanding the character of that space, it exhibits tendencies of a negative anthropology and of stereotyping in teasing out the intersection between narrative moment, anthropology, and stereotype (Ede 2015: 80). Moreover, when we discuss the language of literature, we will find out how it reveals about human thought, as well as cultural and ideological influences on the ways people reason and imagine (Gibbs Jr. and Ferreira 2015: 78).

A narrative moment consists of a 'narratable' event or events and cultural phenomena that take on the nature of 'events' as well. The concept of narrative moment (in both singular and plural senses) is simply one made up of a historical or contemporary event or series of events of large or small import in the public or private sphere, affecting individuals or collectives, that can inspire fictional or factional narratives or even, in a personal sense, the memoir or autobiography. It is important to note that events might have the potential for narration but that narrative moments yield their promise only when actually textualized or rendered into other representational forms (Ede 2015: 80).

Take a look at this phenomenon; people can say how reading Sifiso Nyathi's novel The Other Presence powerfully posits the fact that human beings are homo narrans (story narrators) and that their stories weave diplomatically into the fabric of human thinking, consciousness, fears and hopes for didactic reasons. Through the novel, Nyathi shows how fiction makes the socio-political, cultural and spiritual find concretisation and become more meaningful, resonant, tangible and imaginatively visible (Mlambo and Kandemiri 2015: 131). On the other hand, a literary critic found out that the specificities of narrative genres, which are studied predominantly in non-psychological, literary work, have been ignored (Parker and Shotter 2015: 25).

Moreover, in modern culture, people are split into 'two sides' - one essentially 'literary', the other essentially 'scientific' - unable to communicate with each other, but also, more controversially, that 'traditional culture' and indeed contemporary culture in general remained in thrall to the 'literary intellectuals', actively hostile to science and industry, and therefore impediments to progress and even more so in the developing world (Mandler 2015: 41). 


\section{The problem of criticism}

The problem of literary criticism then arises. It is symptomatic of very important contemporary criticism that it has tended to define the text that is before the reader or critic essentially as an interdependent system of functions. Yet, what has given it an unmistakable cast of radicalism is not the novelty or the scope of its techniques of access to the literary text, or its manner of interpreting it; it has, on the contrary, with compelling logic, insisted that the linguistic material as well as its social and poetological conditions require (or make feasible) a form of understanding and systematized 'reading' that differs in essential respects from the traditional exercise of 'interpretation' (Amacher and Lange 2015: 59).

Literary studies in the United States, during the past few decades, have come to be dominated by approaches that emphasize the social, historical, and political significance of literary works. This development can be attributed both to the exhaustion of more formalist approaches, such as the New Criticism or deconstruction - if it happens forever, like other discipline, literary criticism runs the risk of becoming 'sterile, ineffectual, and hopelessly irrelevant to life' (Pollock, Elman, and Chang 2015: 152) - and to specific historical processes that made certain politically charged approaches to literature suddenly more relevant, as when decolonization eventually led to the rise of postcolonial studies, the Civil Rights movement helped spur approaches focused on race and ethnicity in literature, and the Second Wave feminism inspired gender-based approaches to literature (Booker 2015: 33).

The postcolonial method, to put it simply, means to locate texts and criticism in time and place. The insistence upon this 'worldliness' of texts, is a way of recognizing that they are'always enmeshed in circumstance, time, place, and society - in short, they are in the world, hence worldly'. Following from this, criticism too will require the critic's 'worldly self-situating' and involve an active 'engagement' with texts. This is a 'secular' criticism, secularism being yet another and related meaning of worldliness (Park and Rajan 2015: 138). The next, the process of colonization usually affects socially and culturally, moreover this imperialism occupies for long time. The effects in colonization could be made a myriad of changing socially and culturally like: norms, values, beliefs, and language. The huge problem of identity would be flourished when the colonialists left these colonized countries. The notion of discussing the format of their country and how to regain the identity becomes the salient topic for these countries after colonization era. It is not easy for them due to its influences and also their diversities in tribes, cultures, and languages. This country needs to compromise the old values and new values with all of the people and should dig their social and cultural heritage.

Then, 'modernism' and 'postmodernism' engage in a complicated exchange with poststructuralism. 'Modernism' is generally understood to be a term that applies primarily to art (writers such as William Faulkner or Virginia Woolf and only secondarily to 
thinkers such as Freud). Modernism engages with the subjectivity of the individual as irrational, evanescent but knowable, there to be contemplated - if one can only find the way (Souter 2000: 345). While, postmodernism flourished together with the emerging contemporary literature in the United States. It cannot be separated from the history of writer, history of work, and the history of literature. One of the most popular criticism with the postmodern based is the Black American Movement. The awareness to look for the identity as an African American is pioneered by the writers called The Black Art Movements. This movement is much inspired by the Black Power movement and other movements in other countries, mainly the movement in third world countries in Asia, Africa, and Latin America. Patrice Lumumba, Nelson Mandela, Mao Tse Tung and Che Guevara cannot be separated from the black arts movement in America (Harits, p. 151). Most of the political leaders above fought to free themselves from colonialism and the exploitation politically and economically. The wave of anticolonialism in other countries comes to the United States, and Malcolm X, the black leader, struggles to voice the equality of civil rights in the United States and also calls for abolishment of racism. Such political and social movement finally becomes catalystic for poetry and other literary works of African Americans during the second half of the 1960s and the first half of the 1970s. The racism issues and the struggle to end racial segregation de jure are the central theme in The Black Arts Movements. The writers use such issues to show their identity as black Americans, African Americans.

On the other hand, Kristeva, a great symbol of French feminist literary theory, goes beyond gender differences; she is not female or male focused; according to her, feminist writing has nothing to do with the sex of the author, it is a character inscribed in the text itself that rises at points when the author is generally not in control of the meaning of the text (M. U. Khan 2015: 21). In the United States the writer who is much influenced by his social writer context is Adrienne Rich, American poet. Her ideology as the feminist is shown in her poems. Most of her works talk about the movement of feminism. Because she uses struggle related with feminism. Adrienne Rich is the feminist writer, thus her works, such as her poems, use feminism themes, like motherhood, woman's oppression, and sexuality (Harits, 2012).

Meanwhile, the term 'close reading' is too ideologically radioactive, and means too many different things, to serve as a name for the kind of reading normally. There are various names for it, which turn up in some discussions:'weak reading,' 'minimal reading', 'literal reading', and 'reading for the essentials'. Finally, 'minimal reading' or'minimal interpretation' are settled. Minimal interpretation assumes that good poems taken more or less at face value, as written, are already doing so many interesting things that it is a shame to start weaving ingenious ideas around them too soon - ideas that might be much less inclined to think necessary, or even relevant (Attridge and Staten 2015: 76).

Another approach, cognitive literary criticism, represents a fairly recent and rapidly growing attempt on the part of scholars with many different aims and methods to bring 
literary studies into dialogue with the new sciences of mind and brain. In telling contrast to critics of many other theoretical persuasions, cognitive critics develop their models for understanding subjectivity, agency, consciousness, language, and psychosocial development through critical engagement with the best contemporary work being produced in leading university departments of psychology, linguistics, neuroscience, and philosophy of mind (Waugh 2006: 37). The literary criticism mechanism is also applied to biblical exegesis with the hope that people, especially Christians, can understand it appropriately (Patte 2015: 109).

In Germany, the advances in literary criticism and aesthetics that accompanied the artistic creativity of the Goethean age have long been subjects of scholarly interest. All the time students of a period have sought antecedents for new artistic attitudes. The English garden, the bourgeois tragedy, the sentimental novel, the fairy tale, the poetic descriptions of primordial nature, and the poetic adoration of ruins are regularly considered symptomatic of changes in the premises of taste. The coining of the word 'aesthetics' by Baumgarten, the affirmation of the wondrous by Bodmer and Breitinger, the rejection of predetermined rules by Lessing, and the demand for creative freedom by the Sturm und Drang writers are always mentioned as significant indications of the changes that were taking place (Flaherty 2015: 93).

The presence of cultural studies enriches and strengthens literary criticism. Unfortunately, cultural studies do not have a clearly defined subject area. Its starting point is a very broad and all-inclusive notion of culture that is used to describe and study a whole range of practices (Sardar 2004: 61).

\section{Conclusion}

Then, what should we do with literary criticism? The answer is up to the critics. They have freedom to define their own area. Many aspects have to be revealed in literature. Does literary criticism have to reformulate or change its orientation towards literature? No exact answers are eligible for the question. Above all, readers and audience need the result of literary critics' analysis to strengthen the judgement upon literature. Without careful examination on the vast are of literature, the substance of judgement will be unexpectedly misleading.

\section{References}

Amacher, R., E., \& Lange, V. (2015). New Perspectives in German Literary Criticism: A Collection of Essays. Princeton, New Jersey: Princeton University Press.

Attridge, D., \& Staten, H. (2015). The Craft of Poetry: Dialogues on Minimal Interpretation. London: Routledge. 
Bender, J., B. (2015). Spenser and Literary Pictorialism. Princeton, New Jersey: Princeton University Press.

Booker, M., K. (2015). Literature and Politics Today: The Political Nature of Modern Fiction, Poetry, and Drama: The Political Nature of Modern Fiction, Poetry, and Drama. California: ABC-CLIO.

Cheney, P., \& Silberman, L. (2015). Worldmaking Spenser: Explorations in the Early Modern Age. Lexington, Kentucky: University Press of Kentucky.

Colie, R., L. (2015). My Echoing Song: Andrew Marvell's Poetry of Criticism. Princeton, New Jersey: Princeton University Press.

Destrée, P., \& Murray, P. (2015). A Companion to Ancient Aesthetics. West Sussex, UK: John Wiley \& Sons.

Ede, A. (2015). Narrative Moment and Self-Anthropologizing Discourse. Research in African Literatures 46 (3): 112-129.

Flaherty, G. (2015). Opera in the Development of German Critical Thought. Princeton, New Jersey: Princeton University Press.

Foltz, C. M. (2015). Ezra Pound's Subject Matter and the Poetic Avant-Garde. Journal of Arts and Humanities 4 (10): 86-97.

Frye, N. (2015). Anatomy of Criticism. Princeton, New Jersey: Princeton University Press.

Gates, J. H. L. (2014). The Signifying Monkey: A Theory of African American Literary Criticism. Oxford: Oxford University Press.

Ferreira, L. C., \& Gibbs, J. R. W. (2015). Introduction: why should applied linguists care about Metaphor and Metonymy in Social Practices?. Revista Brasileira De Linguística Aplicada, 15, (2) 303-309. doi:10.1590/1984-639820157138.

Gilazov, T. S., et al. (2015). Karabulatova, I. S., Sayfulina, F. S., Kurakova, C. M., Sayfulina, F. S., Kurakova, C. M., \& Talipova, G. M. (January 01, 2015). Between the East and the West - Phenomenon of Tartar Literary Criticism in the Lingvo-Cultural Aspect. Mediterranean Journal of Social Sciences, 6, 3, 508-517. doi:10.5901/mjss.2015.v6n3s2p508.

Guillen, C. (2015). Literature as System: Essays Toward the Theory of Literary History. Princeton, New Jersey: Princeton University Press.

Hagberg, G., L., \& Walter J. (2015). A Companion to the Philosophy of Literature. West Sussex, UK: John Wiley \& Sons.

Harris, E. A. D. (2015). Venturing More Than a Guess: Self-Actualization through Literary Seminar and Research Effective and meaningful literary research combines concrete, measurable research skills with authentic inquiry and dialogue among peers. English Journal, 105, (2), 70-74.

Harits, I., W. (2015). Constructivism on Literary Teaching:Assimilating Prior Knowledge, social environment, and experiences in D. Zawawi Imron Poems and Black American Poems. e-Pedagogium, (2), 151-158.

Harits. I., W. (2011). The Social Position and Typology of Madurese Women in Madura Folktales. Atavisme. 14, (2), 194-202.

Howells, W., D. (2015). Criticism and Fiction. Lanham: Start Classics.

Huber, M. (2015). Adrift in the Ether: The Market for Literary and Cultural Criticism in the Digital Age. on-line: http://digitalwindow.vassar.edu/cgi/viewcontent.cgi?article=1476\&context=senior_ capstone.

Khan, M., A., H. (2015). Formalism: Perturbations in Twentieth Century Literary Criticism and its Inheritance. Global Journal of Multidisciplinary Studies, 4 (9). on-line: http://gjms.co.in/index. php/gjms/article/view/1147.

Khan, M., U. (2015). Feminist Literary Criticism: The Case Study of Paul Elams Short Story Anger Management. International Journal of Research 2 (1): 514-520.

Leypoldt, G. (2008). Uses of Metaphor: Richard Rorty's Literary Criticism and the Poetics of WorldMaking. New Literary History 39 (1): 145-163, 188. 
Mandler, P. (2015). Ben Pimlott Memorial Lecture 2014 The Two Cultures Revisited: The Humanities in British Universities Since 1945. Twentieth Century British History, 26, 3, 400-423. doi:10.1093/tcbh/hwu068.

Marsden, J., I. (2015). The Re-Imagined Text:Shakespeare, Adaptation, and Eighteenth-Century Literary Theory. Lexington, Kentucky: University Press of Kentucky.

Mlambo, N. \& Kandemiri, C. (2015). Articulating the Unsayable: An Exploration of 'Visible Voices' in Sifiso Nyathi's the Other Presence. Journal of Arts and Humanities 4 (10): 53-64.

Nelson, E. S. (2015). Ethnic American Literature: An Encyclopedia for Students. Santa Barbara, California: ABC-CLIO.

Parker, I. \& Shotter, J. (2015). Deconstructing Social Psychology. New York: Psychology Press.

Park, Y., \& Sunder, R. R. (2000). The postcolonial Jane Austen. London: Routledge.

Patte, D. (2015). What Is Structural Exegesis? Eugene, Oregon: Wipf and Stock Publishers.

Pollock, Sheldon, Benjamin A. Elman, and Ku-ming Kevin Chang. 2015. World Philology. Cambridge; London: Harvard University Press.

Posner, R., A. (2008). The Decline of Literary Criticism. Philosophy and Literature 32 (2): 385-392.

Regaignon, D., R. (2015). Anxious Uptakes: Nineteenth-Century Advice Literature as a Rhetorical Genre. College English 78 (2): 139-161.

Sardar, Z. (2004). Introducing Cultural Studies: A Graphic Guide. Duxford, California: Icon Books.

Schultz, W. (2015). Alistair Heys. The Anatomy of Bloom: Harold Bloom and the Study of Influence and Anxiety. European Journal of American Studies. http://ejas.revues.org/10840.

Souter, K., T. (2000). The Products of the Imagination: Psychoanalitic Theory and Postmodern Literary Criticism. American Journal of Psychoanalysis 60 (4): 341-590.

Stephens, J. (2015). Editorial: Critical Content Analysis and Literary Criticism. International Research in Children's Literature 8 (1): v-viii. doi:10.3366/ircl.2015.0144.

Waugh, P. (2006). Literary Theory and Criticism: An Oxford Guide. Oxford: Oxford University Press.

\section{Contact:}

Dr. Suryo Tri Saksono

University of Trunojoyo Madura, Indonesia

J. Raya Telang, Kecamatan Kamal, Bangkalan, Madura 69162 Indonesia

Imron Wakhid Harits \& doc. Mgr. Štefan Chudý, Ph.D.

Institute of Education and Social Studies

Faculty of Education, Palacký University in Olomouc

Žižkovo nám. 5, 77140 Olomouc, Czech Republic

E-mail: stefan.chudy@upol.cz 